\title{
BATTERED BABY SYNDROME- A MISERABLE CAUSE OF CHILD DEATH
}

\author{
Dara Durga Prasad ${ }^{1}$ Pemmadi Ravi Kumar² \\ ${ }^{1}$ Assistant Professor, Department of Forensic Medicine and Toxicology, Siddhartha Medical College, Vijayawada. \\ ${ }^{2}$ Associate Professor, Department of Forensic Medicine and Toxicology, GITAM Institute of Medical Sciences and Research, \\ Visakhapatnam.
}

\section{ABSTRACT}

\section{BACKGROUND}

One of the important and usual missed causes of paediatric traumas is child abuse. This ominous phenomenon, which can be presented physically, psychologically, sexually and emotionally has grown significantly in recent years. Many children are not diagnosed in the early stages of evaluation. "Battered Child Syndrome" is the word used to describe the clinical condition of the child's serious physical abuse by parents or caregivers. The psychological suffering met by these children is usually huge in addition to the physical trauma. Some of the battered children may even succumb to death.

\section{MATERIALS AND METHODS}

We have studied into it in forensic, socio-political aspects. The series of cases which are taken up for study are of those with age below 10 years and which showed at least some degree of physical child abuse during the years 2015 and 2016 in Krishna and Guntur Districts of Andhra Pradesh state. A total of 41 cases were reported during this period.

\section{RESULTS}

The study showed that the battered children were predominantly of below 5 years age with low socio-economic and educational background. Almost half of the children showed injuries of different ages. The education of the children is also getting disturbed as reflected by frequent absenteeism of children to school. Marital disharmony in parents was frequent. Awareness among parents about child rights was low.

\section{CONCLUSION}

Medical staff should always keep this Battered Baby Syndrome in their mind for those children brought to the Emergency Department with trauma. More children battered are of younger age with poor socio-economic and educational background. Marital disharmonies in parents, lack of awareness on child rights are also a significant cause of this battered baby syndrome. Massive awareness campaigns on child rights, stringent implementation of child protection laws would be the only solution for minimising child trauma.

\section{KEYWORDS}

Paediatric Trauma, Battered Baby Syndrome, Child Death, Awareness Programmes on Child Rights, Minimising Child Trauma.

HOW TO CITE THIS ARTICLE: Prasad DD, Kumar PR. Battered baby syndrome- a miserable cause of child death. J. Evolution Med. Dent. Sci. 2017;6(61):4495-4497, DOI: 10.14260/Jemds/2017/971

\section{BACKGROUND}

Physical abuse is one of the specific types of trauma among childhood and should be considered for all paediatric patients who are referred to the Emergency Department (ED) with inexcusable conditions.(1,2) The reported incidence of child abuse in ED approximately is $2 \%-10 \%$; however, half of these cases are not reported due to fear of jeopardising their reputation.(3) There has been an increasing trend of child abuse not only in India, but also in several other countries like Iran and recent statistics have showed about 3\% - 4\% growth rate during previous years. $\left.{ }^{4}\right) \mathrm{Few}$ of the battered babies are landing into death. To emphasise the importance of this entity we have studied into it in forensic, sociopolitical aspects.

Financial or Other, Competing Interest: None.

Submission 27-04-2017, Peer Review 18-07-2017,

Acceptance 24-07-2017, Published 31-07-2017.

Corresponding Author:

Dr. Dara Durga Prasad,

Flat No. 502, NV Subbayya Residency,

Sri Ramachandra Nagar, Mahanadu Road,

Vijayawada-520007, Andhra Pradesh.

E-mail: dara.ravivarma@gmail.com

DOI: $10.14260 /$ jemds $/ 2017 / 971$

\section{(c) (i) $\$$}

\section{Description}

Child abuse can be in various forms like Physical (Battered baby), Sexual (Paedophilia), chemical poisoning, emotional mistreatment, neglect of a child (Act of omission). It can occur in child's home, schools or in community. Battered baby syndrome is also called as Caffe's syndrome or non-accidental injuries of childhood.(5) It is a clinical condition in which children usually under the age of 3 years are repeatedly beaten over the most trivial provocation. The children are usually unwanted, female, mentally deficient, disabled or step child. The child is frequently deprived of nutrition, care and love. There is delay in the onset of injuries and seeking of medical attention. Cerebral palsy may be the result of battered baby. Usually child is unwanted, step child, disabled or born out of unwanted pregnancy or before marriage. Parents are usually young and isolated family. Parents have low intelligence quotient, low socio-economic status and may have criminal records or psychiatric problems. Parents may be unemployed, disharmonious families or with financial troubles. Parents usually change the history with different doctors. Hallmark of this Battered baby syndrome is repeated trauma over time. Different injuries are seen, which are of different ages with different stage of healing process. Tear of 
frenulum is the most typical injury. Laceration of mucosa of upper lip may also be seen, caused by efforts to silence the child, blow on face or produced by trying to suffocate the child. Vigorous pulling of scalp hair causes subgaleal haematoma and traumatic alopecia. Traction lesions of periosteum of long bones without fractures may be seen with old ones seen radiologically as an extra line of opacity along the length of the long bone. Antero-posterior chest compressions cause fractures at costochondral junctions. Subdural Haematoma is seen in about $40 \%$ of cases. Diagnosis can be made by the delay in time taken to seek medical advice, nature of injuries and their recurrence, imaging by X-rays and MRI, old fractures, epiphyseal and metaphyseal injuries in various stages of healing. Head injury, rupture of internal organs are the most common cause of death. $(6,7)$

\section{MATERIALS AND METHODS}

The series of cases which are taken up for study are of those with age below 10 years and which showed at least some degree of physical child abuse. The study was done during the years 2015 and 2016. Region in which cases were studied were districts Krishna and Guntur of Andhra Pradesh State. Case information from all sources were sought like children brought to casualty, autopsy, newspaper reports and information from police/ investigative authorities. In this study on physically abused children aspects like age and sex distribution, outcome of the abuse, severity of the injuries, age of injuries, presenting time, history of injury by the parents, socio-economic class, marital harmony in the parents, education of children, autopsy findings and awareness of parents about child rights are studied.

\section{RESULTS}

Total 41 cases were reported, of which 2 children were dead and brought to autopsy; 20 cases were male and 21 were female. 40 cases were of below 5 years age, one was of 8 years age. 21 cases showed minor injuries, 20 cases showed multiple injuries of different ages and the history said by the parents did not match with the injuries. All are of low socioeconomic group. In 33 cases children are living together with their parents; in 3 cases parents were divorced; in 2 cases parents were living separately; and in 3 cases parents were having extramarital sexual relations. In 20 cases there was routine formal education. In 3 cases there was no formal education. In 8 cases, there was frequent absenteeism to school. The remaining 10 cases were of pre-school age group. The two cases over which autopsy was done showed multiple external and internal injuries. Subdural haematoma was the cause of death in both the cases. One case showed liver laceration. In all the cases, in the parents there was no proper awareness about child rights and the legal consequences of child abuse.

\begin{tabular}{|c|c|c|c|c|}
\hline $\begin{array}{c}\text { Sl. } \\
\text { No. }\end{array}$ & \multirow{2}{*}{ Criteria } & $\begin{array}{c}\text { Out of Total } \\
\text { 41 Cases }\end{array}$ & $\begin{array}{c}\text { No. of } \\
\text { Cases }\end{array}$ & $\begin{array}{c}\text { Percentage } \\
\text { \% }\end{array}$ \\
\hline \multirow{2}{*}{ 1) } & Alive or & Alive & 39 cases & $95 \%$ \\
\cline { 3 - 5 } & Dead & Dead & 2 cases & $5 \%$ \\
\hline \multirow{2}{*}{$2)$} & \multirow{2}{*}{ Sex } & Male & 20 cases & $49 \%$ \\
\cline { 3 - 5 } & & Female & 21 cases & $51 \%$ \\
\hline
\end{tabular}

\begin{tabular}{|c|c|c|c|c|}
\hline \multirow{2}{*}{ 3) } & \multirow{2}{*}{ Age } & $<5$ years & 40 cases & $97 \%$ \\
\hline & & 5 - 10 years & 1 case & $3 \%$ \\
\hline \multirow{2}{*}{ 4) } & \multirow{2}{*}{$\begin{array}{l}\text { Degree of } \\
\text { Injury }\end{array}$} & Minor & 21 cases & $51 \%$ \\
\hline & & Severe & 20 cases & $49 \%$ \\
\hline \multirow{2}{*}{ 5) } & \multirow{2}{*}{$\begin{array}{c}\text { Age of } \\
\text { Injuries }\end{array}$} & Same & 21 cases & $51 \%$ \\
\hline & & Different & 20 cases & $49 \%$ \\
\hline \multirow[b]{2}{*}{ 6) } & \multirow{2}{*}{$\begin{array}{c}\text { History of } \\
\text { Injury as said } \\
\text { by Parents }\end{array}$} & Matching & 21 cases & $51 \%$ \\
\hline & & Mismatch & 20 cases & $49 \%$ \\
\hline \multirow[b]{2}{*}{ 7) } & \multirow{2}{*}{$\begin{array}{c}\text { Socio- } \\
\text { Economic } \\
\text { Status }\end{array}$} & Low & 41 cases & $100 \%$ \\
\hline & & $\begin{array}{c}\text { Middle/ } \\
\text { High }\end{array}$ & 0 cases & $0 \%$ \\
\hline \multirow[b]{2}{*}{ 8) } & \multirow{2}{*}{$\begin{array}{c}\text { Awareness } \\
\text { on Child } \\
\text { Rights in } \\
\text { Parents }\end{array}$} & Poor & 41 cases & $100 \%$ \\
\hline & & Good & 0 cases & $0 \%$ \\
\hline \multirow{4}{*}{ 9) } & \multirow{4}{*}{$\begin{array}{c}\text { Marital } \\
\text { Harmony }\end{array}$} & $\begin{array}{l}\text { Parents and } \\
\text { Children } \\
\text { living together }\end{array}$ & 33 cases & $81 \%$ \\
\hline & & $\begin{array}{c}\text { Parents with } \\
\text { Extramarital } \\
\text { Affairs }\end{array}$ & 3 cases & $7 \%$ \\
\hline & & $\begin{array}{c}\text { Parents Living } \\
\text { Separately } \\
\text { without Formal } \\
\text { Divorce } \\
\end{array}$ & 2 cases & $5 \%$ \\
\hline & & \begin{tabular}{|c|} 
Divorced \\
Parents \\
\end{tabular} & 3 cases & $7 \%$ \\
\hline \multirow{4}{*}{ 10) } & \multirow{4}{*}{$\begin{array}{c}\text { Child } \\
\text { Education }\end{array}$} & Pre-School Age & 10 cases & $24 \%$ \\
\hline & & \begin{tabular}{|c|} 
Regular \\
Education \\
\end{tabular} & 20 cases & $49 \%$ \\
\hline & & $\begin{array}{c}\text { Frequent } \\
\text { Absenteeism }\end{array}$ & 8 cases & $19 \%$ \\
\hline & & $\begin{array}{l}\text { No Formal } \\
\text { Education }\end{array}$ & 3 cases & $8 \%$ \\
\hline
\end{tabular}

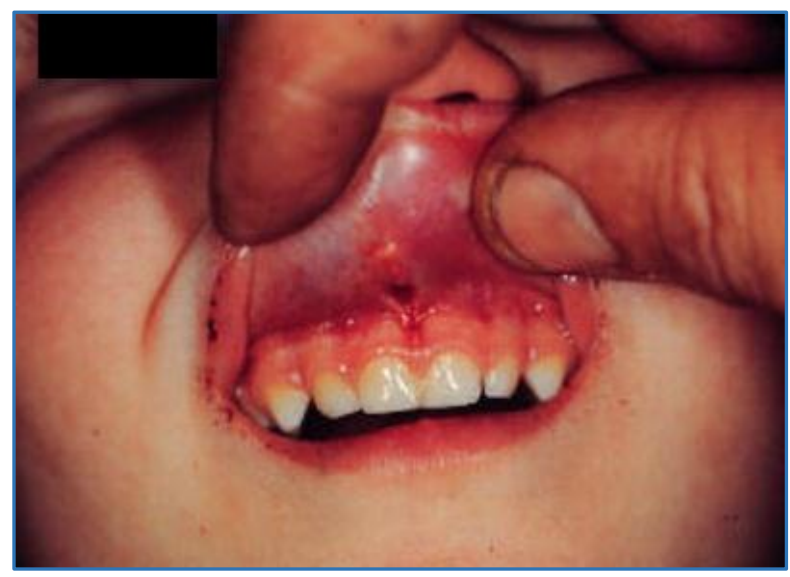

Frenulum Tear 


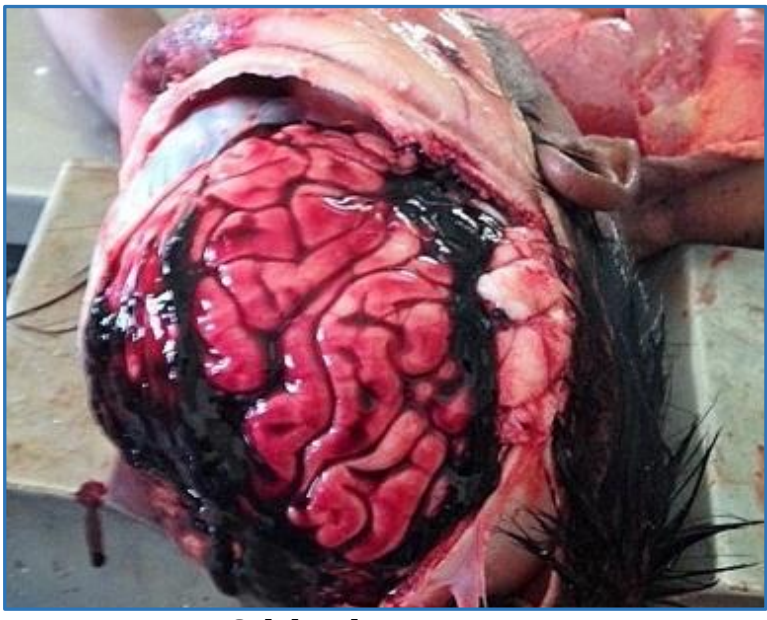

Subdural Haematoma

\section{DISCUSSION}

Children being battered to death, though statistically low, is an alarming situation. Slight female predominance is present in battered babies. Battered children are predominantly of below 5 years age. Almost half of the presented cases had severe injuries and about half of the cases showed injuries of different ages, which implies that the children are being abused over a period of time. Almost half of the parents denied battering their children, which is the cause of the injury. Battered children in low socio-economic groups is high and there could be low case reporting in high socioeconomic groups. None of them have adequate awareness about child rights. Results show that parent's marital harmony plays a significant role over child care. An injury to children is making them incapable of attending school regularly.

Every parent is a potential "baby basher." There can be very few parents who at one time or other have not been exasperated beyond endurance by the behaviour of their children. As a certain measure of physical abuse of children is condoned by cultures, a "normal" aspect of child rearing parents placed under enough pressure however kind they may appear under normal circumstances will batter their children. Several women in India are married when they are a child (before the age of 18 ) and about $30 \%$ of them bear a child when they are a child (adolescent mothers). There are several laws in India meant for protection and welfare of children like "The Protection of Children from Sexual Offences Act 2012., The Right of Children to Free and Compulsory Education Act 2009, Juvenile Justice (Care and Protection of Children) Act 2000, Child Labour (Prohibition and Regulation) Act 1986, Infant Milk Substitutes, Feeding Bottles and Infant Foods, Prohibition of Child Marriage Act 2006, Immoral Traffic Prevention Act 1986, Guardians and Wards Act 1890, Hindu Adoption and Maintenance Act 1956, etc. But there exist several lacunae in their implementation, which is resulting in low conviction. There is almost no knowledge in the people of lower socio-economic groups about child rights. All these are leaving several innocent children in severe troubles.

\section{Suggestions for Prevention}

Massive campaigns should be conducted to educate the public about child rights and penalty for child abuse. Laws should be made effectively and their implementation shall be given equal importance. Early marriages should be prevented, so that the parents get enough mental maturity before they bear children. All cases of battered baby cases should be made medico-legal cases, so that there will be increased reporting which in turn will help in prevention by effective counselling, legal penalty, etc. While every effort must be made to rehabilitate battering parents, this effort should not be at the expense of the safety of the child. Doctors should be adequately trained and sensitised, so that they properly identify these cases, report and treat them efficiently.

\section{CONCLUSION}

Children being battered is no sign of civilisation in this modern world. As evident by the results of the study, few battered children have even succumbed to death. The injuries were of different ages. More children battered are of younger age with poor socioeconomic and educational background. Marital disharmonies and lack of awareness on child rights are playing their part. Education of the children is also getting disturbed. Sensitivity in society towards children's sufferings should be increased. Massive awareness campaigns on child rights, stringent implementation of child protection laws would be the solution for minimising child trauma. Medical staff should always keep the syndrome in their mind for those brought to the emergency department with trauma.

\section{REFERENCES}

[1] Reid JA. Battered-child syndrome. In: Fisher BS, Lab SP, (eds). Encyclopedia of victimology and crime prevention. Thousand Oaks: CA: Sage Publications 2010:28-30.

[2] Dvorak S, Howe TR. Battered child syndrome. In: Goldstein S, (edr). Encyclopedia of child behavior and development. United State: Springer US 2011:212-301.

[3] Sedlak AJ, Mettenburg J, Basena M, et al. Fourth national incidence study of child abuse and neglect (NIS-4). Washington, DC: US department of health and human services, administration for children and families 2010.

[4] Mohammadi MR, Zarafshan H, Khaleghi A. Child abuse in Iran: a systematic review and meta-analysis. Iran J Psychiatry 2014;9(3):118-24.

[5] Agarwal A. Text book of forensic medicine \& toxicology. $1^{\text {st }}$ edn. Avichal publishing company, New Delhi 2017:489-504.

[6] Pillay VV. Text book of forensic medicine \& toxicology. $16^{\text {th }}$ edn. Paras medical publishers, Hyderabad 2011:330-60.

[7] Reddy KSN, Murthy OP. Essentials of forensic medicine \& toxicology. $33^{\text {th }}$ edn. Jaypee publishers, New Delhi 2015:365-82. 